\title{
Control of Postharvest Fungal Rots on Grapes Using Essential Oil of Foeniculum vulgare Mill.
}

\author{
Carine Pedrotti ${ }^{1}$, Rute T. S. Ribeiro ${ }^{1}$ \& Joséli Schwambach ${ }^{1}$ \\ ${ }^{1}$ Laboratory of Plant Disease Control and Laboratory of Plant Biotechnology, Institute of Biotechnology, \\ University of Caxias do Sul, Caxias do Sul, RS, Brazil
}

Correspondence: Joséli Schwambach, Laboratory of Plant Disease Control and Laboratory of Plant Biotechnology, Institute of Biotechnology, University of Caxias do Sul, Street Francisco Getúlio Vargas, 1130 Petrópolis, 95070-560, Caxias do Sul, RS, Brazil. Tel: 55-54-3218-2100. E-mail: joselischwambach@gmail.com

Received: January 20, 2017

Accepted: February 21, 2017 Online Published: March 15, 2017

doi:10.5539/jas.v9n4p205

URL: https://doi.org/10.5539/jas.v9n4p205

\begin{abstract}
Fungal rots, caused by Botrytis cinerea and Colletotrichum acutatum, are the main causes of postharvest decay of table grapes in Brazil. The aim of this study was to assess the chemical composition and the fungicidal effect of Foeniculum vulgare essential oil in vitro, on mycelial growth (contact and volatile phase) and conidia germination, and in vivo on postharvest grapes against both fungi. The major compounds found in $F$. vulgare essential oil were trans-anethole (79.14\%), fenchone (11.94\%) and estragole (5.76\%). The mycelial growth (contact phase) and conidia germination of $B$. cinerea were inhibited completely at concentrations of 50 and 100 ppm $\left(\mu \mathrm{L} \mathrm{mL}{ }^{-1}\right)$, respectively. For $C$. acutatum, mycelial growth (contact phase) and conidia germination were inhibited completely at concentrations of 100 and $200 \mathrm{ppm}$, respectively. The volatile phase had a fungistatic effect on mycelial growth of both fungi at different concentrations tested, and the pure essential oil (100\%) presented fungicidal effect against $B$. cinerea. In vivo tests were carried out using grapes of Vitis spp. cv. "Isabella" and the concentrations of essential oil tested were efficient, reducing the incidence of disease caused by B. cinerea and C. acutatum at postharvest, both in preventive and curative treatment. The concentration 200 ppm completely inhibited the incidence of both fungi. In conclusion, $F$. vulgare essential oil presented fungicidal action against postharvest fungal rots on grapes.
\end{abstract}

Keywords: alternative control, Botrytis cinerea, Colletotricum acutatum, fennel, Vitis spp.

\section{Introduction}

Grape is one of the most important fruit crops worldwide. In Brazil, grape production destined for processing (wine, juice and derivatives) was 673.422 million kilos in 2014, representing $46.89 \%$ of the national production. The remaining production (53.11\%) was intended for consumption in natura (Mello, 2014). "Isabella" grape is one of the most important varieties of Vitis spp. and it is the most diffused variety in the Serra Gaúcha, the southern viticultural region of Brazil, where it represents near $57 \%$ of the total production. "Isabella" grape is used to make red table wine and juice and it is also commercialized as table grape (Mello, 2014; Silveira, Hoffmann, \& Garrido, 2015).

The economic losses due to fungal infection in fruit and vegetables within the postharvest chain are variable and not well documented and they usually reach any where from 30 to $50 \%$ and on some occasions rots can lead to total loss of the produce (Smilanick, Brown, \& Eckert, 2006; Youssef \& Roberto, 2014). Botrytis cinerea Pers. Fr. and Colletotrichum acutatum Simmonds cause fungal rot on a large number of economically important agricultural crops and they are considered the main cause of great losses of postharvest in table grapes (Pearson \& Goheen, 1988; Peres, Kuramae, Dias, \& Souza, 2002; Steel, Greer, \& Savocchia, 2007; Whitelaw-Weckert et al., 2007).

By over efficient that it is the phytosanitary treatment made in the field, it is not enough to dismiss it in postharvest (Lichter et al., 2002). As a postharvest treatment, grapes are usually stored with sulfur dioxide fumigation (Droby \& Lichter, 2004). However, the use of synthetic fungicides and sulfur dioxide is not allowed on organic grapes (Mlikota Gabler \& Smilanick, 2001). In addition, the growing public concerns about health and environmental hazards associated with pesticide use have resulted in a considerable interest in developing alternative non-polluting control methods (Youssef \& Roberto, 2014). 
Several studies have proven the effect of extracted compounds isolated from essential oils of plants, which act as natural fungicides inhibiting fungal activity (Chao \& Young, 2000). Moreover, the majority of essential oils are classified by the FDA (Food and Drug Administration) as GRAS (Generally Recognized as Safe), recognized as safe for use in foods, so there has been a growing interest in using them in the treatment of fruits and vegetables (Gonzáles-Aguilar et al., 2008).

Fennel (Foeniculum vulgare Mill.) is a small genus of annual, biennial or perennial herbs. It is widely cultivated throughout the temperate and tropical regions of the world for its aromatic fruits, which are used as a culinary spice (Diaz-Maroto, Pearez-Coello, Esteban, \& Sanz, 2006; Rather, Dar, Sofi, Bhat, \& Qurishi, 2012). Mature fennel fruit and its essential oil are used as flavoring agents in food products and also as a constituent in cosmetic and pharmaceutical products (Rather et al., 2012; Telci, Demirtas, \& Sachin, 2009). Moreover there are reports on various biological activities of the essential oil, such as hepatoprotective effect (Ozbek et al., 2003), antidiabetic activity (El-Soud et al., 2011), antitumor activity (Pradhan et al., 2008), antioxidant activity (Ruberto, Baratta, Deans, \& Dorman, 2000; Singh, Maurya, Lampasona, \& Catalan, 2006), antithrombotic activity (Tognolini et al., 2007), anti-inflammatory activity (Choi \& Hwang, 2004) and acaricidal activity (Lee, 2004). In addition, the essential oil of fennel fruits had significant antifungal activity against various phytopathogens (Singh et al., 2006; S. Soylu, Yigitbas, E. M. Soylu, \& Kurt, 2007).

The aim of this study was to identify the chemical composition and evaluate the fungicidal effect of Foeniculum vulgare essential oil in vitro, on mycelial growth (contact and volatile phase) and conidia germination, and in vivo on postharvest grapes against B. cinerea and C. acutatum.

\section{Material and Methods}

\subsection{Isolated Fungi}

Strains of B. cinerea (A58/09) and C. acutatum (A009/13) used in this work were isolated from grapes of Caxias do Sul (Serra Gaúcha, RS, Brazil) and preserved in the fungal collection of the Laboratory of Phytopathology, University of Caxias do Sul, Brazil, on PDA (Potato Dextrose Agar) medium. The molecular confirmation of both fungi was done using Internal Transcribed Sequence (ITS)-PCR identification. The DNA extraction was according to Murray and Thompson (1980) and ITS-PCR amplified the region ITS-5.8S rDNA according to White, Bruns, Lee, and Taylor (1990). Sequencing was proceed at the Human Genome Center-USP and the sequences obtained were edited with the software BioEdit Sequence Alignment Editor (1997-2005) and used to search for similar sequences using Blastn at NCBI.

\subsection{Plant Material}

Fruits in the final stage of maturation of $F$. vulgare were collected from plants localized in the city of Caxias do Sul, Brazil. A voucher specimen of the plant species was deposited in the Herbarium of the University of Caxias do Sul with number 44057.

\subsection{Essential Oils Extraction and Analysis}

The essential oil was extracted by hydrodistillation from dried fruits for 1 hour in a Clevenger-type apparatus according to Agostini et al. (2009). For identification and quantification of compounds of the essential oil, it was used the protocol described in Tomazoni et al. (2016) using a gas chromatograph HP 6890, coupled with a mass selective detector Hewlett Packard MSD5973, equipped with HP Chemstation software and Wiley 275 spectra data. The analyses were conducted using a fused silica capillary column HP-Innowax $(30 \mathrm{~m} \times 0.25 \mathrm{~mm}$ i.d., 0.25 $\mu \mathrm{m}$ film thickness, Hewlett Packard, Palo Alto, USA). The components were identified by a combination of mass spectrum of the Wiley library and by comparison with data from literature (Adams, 2005). The relative percentage of each component was obtained from chromatographic peak areas, assuming the sum of all eluted peaks being $100 \%$.

\subsection{In vitro Antifungal Assay}

\subsubsection{Antifungal Activity of Essential Oil on Mycelial Growth}

The antifungal properties of essential oil were assessed for its contact and volatile phase effects towards mycelial growth of phytopathogens. Contact phase effect of essential oil was tested according to Feng and Zheng (2007) with minor modifications. Essential oils concentrations used were 10, 50, 100 and $200 \mathrm{ppm}\left(\mu \mathrm{L} \mathrm{mL}^{-1}\right)$, with the addition of Tween 20 (1:1), diluted on autoclaved and melting PDA (Potato Dextrose Agar) $\left(40^{\circ} \mathrm{C}\right)$ under aseptic conditions. The control treatment was just PDA medium with addition of Tween 20 at concentration $200 \mathrm{ppm}$ (similar to the highest concentration used to emulsify the essential oil). These emulsions were poured into $9 \mathrm{~cm}$ 
(Ø) Petri dishes and, after medium solidification, inoculated with $5 \mathrm{~mm}(\varnothing)$ agar disks colonized by $B$. cinerea or C. acutatum mycelium with seven days of development.

To assess fungicidal action of the volatile phase of essential oil on the mycelial growth of fungi it was utilized the methodology according to Silva (2012) with minor modifications. Agar disks with $5 \mathrm{~mm}(\varnothing)$ colonized by $B$. cinerea or C. acutatum mycelium with seven days of development were placed in the center of the Petri dish containing PDA culture medium. The concentrations of essential oils used were 12.5, 25, 50 with the addition of Tween $20(0.1 \%)$ and $100 \%$ (pure essential oil, without addition of Tween 20). A $100 \mu \mathrm{L}$ sample of pure essential oil and the solutions were applied onto a cotton ball attached to the inner face of a Petri dish lid, thereby preventing direct contact of the oil with the culture medium and the mycelium disk, creating a saturated atmosphere of volatile compounds. The control treatment was just PDA medium and $100 \mu \mathrm{L}$ of Tween $20(0.1 \%)$ applied onto a cotton ball.

In both tests, for each concentration, ten replicate plates were used. Incubation was performed at $25{ }^{\circ} \mathrm{C}$ temperature and 12 hours photoperiod, during fourteen days. Fungal growth was recorded on the $3^{\text {rd }}, 5^{\text {th }}, 7^{\text {th }}, 10^{\text {th }}$ and $14^{\text {th }}$ day by measuring the orthogonal diameter of the fungi. Transfer experiments were performed to provide a distinction between the fungistatic and fungicidal effects of essential oil on the target microorganisms. For this purpose, plugs that did not grow were transferred to fresh PDA dishes to assess their viability and growth after five days of inoculation at $25{ }^{\circ} \mathrm{C}$ temperature and 12 hours photoperiod. The residual fungal growth was monitored by measuring the orthogonal diameter of the fungi.

\subsubsection{Antifungal Activity of Essential Oil on Conidia Germination}

Antifungal activity of essential oil on conidia germination was tested according to Badawy and Rabea (2013), with minor modifications. Conidia of B. cinerea and C. acutatum were harvested from a colony of the fungi 14 days grown in PDA at $25{ }^{\circ} \mathrm{C}$ temperature and 12 hours photoperiod. Five milliliter of sterile water was added to a Petri plate culture. The conidia were gently dislodged from the surface with a sterile glass rod and the suspension was filtered through three layers of cheesecloth to remove mycelia fragments. The suspension was diluted with sterile water to obtain a suspension of $1 \times 10^{6}$ conidia $\mathrm{mL}^{-1}$. Aliquots of conidia suspension $(50 \mu \mathrm{L})$ were placed in microtubes containing $500 \mu \mathrm{L}$ of PDB (Potato Dextrose Broth) medium treated with essential oils, at the concentrations of 10,50,100 and $200 \mathrm{ppm}$, with the additon of Tween 20 (1:1). The control treatment was just PDB with addition of Tween 20 at concentration $200 \mathrm{ppm}$ (similar to the highest concentration used to emulsify the essential oil). The tubes were incubated at $25{ }^{\circ} \mathrm{C}$ for 16 hours. The samples were placed on a Neubauer chamber and observed under the microscope for conidia germination. The counting of conidia was done using a light microscopy at $10 \times$ magnification. All experiments were conducted in ten replicates and in each replicate were evaluated hundred conidia. The conidia were considered germinated when the length of the germ tube equaled or exceeded the length of the conidia.

\subsection{In vivo Antifungal Assay}

\subsubsection{Inoculum Preparation}

Conidia of B. cinerea and C. acutatum were harvested from a colony of the fungi 14 days grown in PDA at $25^{\circ} \mathrm{C}$ temperature and 12 hours photoperiod as described above. The suspension was diluted with sterile water to obtain a suspension of $1 \times 10^{6}$ conidia $\mathrm{mL}^{-1}$.

\subsubsection{Fruit}

Traditionally grown and freshly harvested grapes of cultivar "Isabella" from Bento Gonçalves, RS, Brazil were used in in vivo experiments.

\subsubsection{Antifungal Activity of Essential Oil on Grapes}

To evaluate the antifungal activity of the essential oil on grapes it was carried out experiments with curative and preventive treatments. The postharvest curative treatment consisted of inoculation of 10 berries for each cluster (10 fruit/treatment) of grape, through wounds, approximately $2 \mathrm{~mm}$ deep, with the aid of a syringe (Zahavi et al., 2000). After the injury, the clusters were inoculated by spraying the conidia suspension of $B$. cinerea or $C$. acutatum, according to the methodology described by Romanazzi, Nigro, Ippolito, Di Venere, and Salermo (2002) and Thomas, Marois, and English (1988) with modifications. After 4 hours, the application of essential oil was carried out with the concentrations based on the in vitro test (50,100 and $200 \mathrm{ppm})$. Subsequently, in order to evaluate the potential of oil in preventing disease, the grape clusters were sprinkled with essential oil in the same concentrations of the previous test and inoculated after 24 hours with the fungi. For both experiments, the clusters were placed in plastic boxes and kept at $25 \pm 1{ }^{\circ} \mathrm{C} / 80-90 \%$ relative humidity for a period of five days for those inoculated with B. cinerea and seven days for those inoculated with C. acutatum. At the end of this period, 
assessment of the incidence and severity of disease was performed. To evaluate the incidence, ten berries for each bunch of grapes that were inoculated were evaluated and it was used the mean number of berries with symptoms of the disease. For assessing the severity, a scale from 0 to $100 \%$ was created in accordance with the berry area affected by the disease.

2.6 Statistical Analysis

Data normality was determined by Kolmogorov-Smirnov test and the homogeneity of variances was determined using Levene's test. Data were analyzed by ANOVA and the threshold for statistical significance was set at $\mathrm{p}<$ 0.05. In the case of statistical significance Dunnett's T3 test was applied to separate the means. All statistics analysis was performed using SPSS 22.0 for Windows.

\section{Results}

\subsection{Chemical Composition of the Essential Oil}

A total of 09 components of the essential oil were identified by GC-MS, representing $99.95 \%$ of the total amount (Table 1). The most abundant components of the $F$. vulgare essential oil were trans-anethole (79.14\%), fenchone $(11.94 \%)$ and estragole (5.76\%). Other components such as limonene $(1.01 \%)$, anisaldehyde $(0.96 \%)$, 1,8 -cineole $(0.39 \%), \alpha$-pinene $(0.30 \%), \beta$-thujene $(0.25 \%)$ and camphor $(0.20 \%)$ were present in lower amounts.

Table 1. Chemical composition of essential oil from Foeniculum vulgare fruits

\begin{tabular}{lll}
\hline Compounds & RI $^{\mathbf{1}}$ & Peak area $(\%)^{\mathbf{2}}$ \\
\hline$\alpha$-pinene & 8.204 & 0.30 \\
$\beta$-thujene & 16.526 & 0.25 \\
Limonene & 18.232 & 1.01 \\
1,8-cineole & 18.730 & 0.39 \\
Fenchone & 28.908 & 11.94 \\
Camphor & 34.540 & 0.20 \\
Estragole & 41.320 & 5.76 \\
Trans-anethole & 47.721 & 79.14 \\
Anisaldehyde & 54.970 & 0.96 \\
\hline
\end{tabular}

Note. ${ }^{1}$ RI, the retention index published by Adams; ${ }^{2}$ Peak area obtained by GC-FID.

\subsection{In vitro Antifungal Effect of F. vulgare Essential Oil}

\subsubsection{Antifungal Activity of Essential Oil on Mycelial Growth}

The in vitro antifungal activity of essential oil differed for each fungi and concentration tested at contact phase experiments (Table 2). The effect of essential oil on the mycelial growth of $B$. cinerea resulted in completely inhibition at concentration $50 \mathrm{ppm}$ and the fungicidal action was observed by the transfer experiment. For the concentration $10 \mathrm{ppm}$ there was a significant inhibition until the $5^{\text {th }}$ day compared to control, also the mycelial growth presented a different morphology. On the other hand, the completely inhibition of the mycelial growth of C. acutatum occurred at a higher concentrations $(100$ and $200 \mathrm{ppm})$ with fungicidal action proven by the transfer experiment. The concentration $10 \mathrm{ppm}$ presented a fungistatic action until the $3^{\text {rd }}$ day, and the same was observed for concentration $50 \mathrm{ppm}$ until the $10^{\text {th }}$ day, being significantly different from control. Both concentrations presented a modified morphology for the mycelial growth. 
Table 2. Effect of different concentrations of Foeniculum vulgare essential oil, added on the solid media, on the mycelial growth of Botrytis cinerea and Colletotrichum acutatum (contact phase)

\begin{tabular}{llllll}
\hline & \multicolumn{5}{c}{ Mycelial growth $(\mathrm{mm})$} \\
\cline { 2 - 6 } & 0 & 10 & 50 & 100 & $200(\mathrm{ppm})$ \\
\hline B. cinerea & $47.75 \pm 2.07 \mathrm{a}$ & $14.80 \pm 1.26 \mathrm{~b}$ & $0.00 \pm 0.00 \mathrm{c}$ & $0.00 \pm 0.00 \mathrm{c}$ & $0.00 \pm 0.00 \mathrm{c}$ \\
$3^{\text {rd }}$ day & $90.00 \pm 0.00 \mathrm{a}$ & $73.53 \pm 2.37 \mathrm{~b}$ & $0.00 \pm 0.00 \mathrm{c}$ & $0.00 \pm 0.00 \mathrm{c}$ & $0.00 \pm 0.00 \mathrm{c}$ \\
$5^{\text {th }}$ day & $90.00 \pm 0.00 \mathrm{a}$ & $81.88 \pm 3.58 \mathrm{a}$ & $0.00 \pm 0.00 \mathrm{~b}$ & $0.00 \pm 0.00 \mathrm{~b}$ & $0.00 \pm 0.00 \mathrm{~b}$ \\
$7^{\text {th }}$ day & $90.00 \pm 0.00 \mathrm{a}$ & $82.53 \pm 3.33 \mathrm{a}$ & $0.00 \pm 0.00 \mathrm{~b}$ & $0.00 \pm 0.00 \mathrm{~b}$ & $0.00 \pm 0.00 \mathrm{~b}$ \\
$10^{\text {th }}$ day & $90.00 \pm 0.00 \mathrm{a}$ & $82.75 \pm 3.28 \mathrm{a}$ & $0.00 \pm 0.00 \mathrm{~b}$ & $0.00 \pm 0.00 \mathrm{~b}$ & $0.00 \pm 0.00 \mathrm{~b}$ \\
$14^{\text {th }}$ day & & & & & \\
\hline$C$. acutatum & $17.11 \pm 0.39 \mathrm{a}$ & $13.23 \pm 0.60 \mathrm{~b}$ & $0.00 \pm 0.00 \mathrm{c}$ & $0.00 \pm 0.00 \mathrm{c}$ & $0.00 \pm 0.00 \mathrm{c}$ \\
$3^{\text {rd }}$ day & $39.99 \pm 1.38 \mathrm{a}$ & $34.50 \pm 0.90 \mathrm{a}$ & $6.34 \pm 2.25 \mathrm{~b}$ & $0.00 \pm 0.00 \mathrm{~b}$ & $0.00 \pm 0.00 \mathrm{~b}$ \\
$5^{\text {th }}$ day & $55.08 \pm 3.17 \mathrm{a}$ & $50.06 \pm 1.71 \mathrm{a}$ & $19.90 \pm 3.45 \mathrm{~b}$ & $0.00 \pm 0.00 \mathrm{c}$ & $0.00 \pm 0.00 \mathrm{c}$ \\
$7^{\text {th }}$ day & $72.08 \pm 4.35 \mathrm{a}$ & $63.67 \pm 2.52 \mathrm{a}$ & $43.78 \pm 3.21 \mathrm{~b}$ & $0.00 \pm 0.00 \mathrm{c}$ & $0.00 \pm 0.00 \mathrm{c}$ \\
$10^{\text {th }}$ day & $83.09 \pm 3.77 \mathrm{a}$ & $77.08 \pm 1.67 \mathrm{a}$ & $69.41 \pm 3.12 \mathrm{a}$ & $0.00 \pm 0.00 \mathrm{~b}$ & $0.00 \pm 0.00 \mathrm{~b}$ \\
$14^{\text {th }}$ day &
\end{tabular}

Note. Values are the average of ten replicates per treatment \pm SE. The letters indicate the comparison among the different essential oil concentrations evaluated in each day (per line). Means followed by same letter do not differ by Dunnett's T3 test $(\mathrm{p}<0.05)$.

The effect of the volatiles compounds in the mycelial growth of B. cinerea showed a total inhibition at $100 \%$ concentration (fungicidal action was confirmed by transfer experiment) and for C. acutatum the same concentration reduced the mycelial growth but do not complete inhibited it (Table 3). At the concentration of $25 \%$, growth was complete inhibited until $7^{\text {th }}$ day, and the concentration of $50 \%$ inhibited the growth until $10^{\text {th }}$ day of $B$. cinerea, showing that maybe a reapplication of the essential oil could control the growth of the fungus.

Table 3. Effect of different concentrations of Foeniculum vulgare essential oil, applied on the lid, on the mycelial growth of Botrytis cinerea and Colletotrichum acutatum (volatile phase)

\begin{tabular}{llllll}
\hline & \multicolumn{5}{c}{ Mycelial growth $(\mathrm{mm})$} \\
\cline { 2 - 6 } & 0.0 & 12.5 & 25 & 50 & $100(\%)$ \\
\hline B. cinerea & $57.94 \pm 5.17 \mathrm{a}$ & $0.00 \pm 0.00 \mathrm{~b}$ & $0.00 \pm 0.00 \mathrm{~b}$ & $0.00 \pm 0.00 \mathrm{~b}$ & $0.00 \pm 0.00 \mathrm{~b}$ \\
$3^{\text {rd }}$ day & $84.11 \pm 2.53 \mathrm{a}$ & $8.47 \pm 3.08 \mathrm{~b}$ & $0.00 \pm 0.00 \mathrm{~b}$ & $0.00 \pm 0.00 \mathrm{~b}$ & $0.00 \pm 0.00 \mathrm{~b}$ \\
$5^{\text {th }}$ day & $85.59 \pm 2.32 \mathrm{a}$ & $38.53 \pm 8.81 \mathrm{~b}$ & $0.00 \pm 0.00 \mathrm{c}$ & $0.00 \pm 0.00 \mathrm{c}$ & $0.00 \pm 0.00 \mathrm{c}$ \\
$7^{\text {th }}$ day & $85.92 \pm 2.11 \mathrm{a}$ & $85.89 \pm 2.42 \mathrm{a}$ & $47.98 \pm 10.2 \mathrm{ab}$ & $0.00 \pm 0.00 \mathrm{~b}$ & $0.00 \pm 0.00 \mathrm{~b}$ \\
$10^{\text {th }}$ day & $87.88 \pm 1.42 \mathrm{a}$ & $88.78 \pm 0.82 \mathrm{a}$ & $77.54 \pm 6.03 \mathrm{a}$ & $19.29 \pm 5.01 \mathrm{~b}$ & $0.00 \pm 0.00 \mathrm{~b}$ \\
$14^{\text {th }}$ day & & & & & \\
$-C$. acutatum & $22.80 \pm 1.71 \mathrm{a}$ & $12.81 \pm 1.50 \mathrm{ab}$ & $12.86 \pm 0.88 \mathrm{ab}$ & $10.91 \pm 0.45 \mathrm{ab}$ & $3.62 \pm 1.85 \mathrm{~b}$ \\
$3^{\text {rd }}$ day & $36.71 \pm 1.28 \mathrm{a}$ & $26.85 \pm 2.46 \mathrm{ab}$ & $25.59 \pm 1.85 \mathrm{ab}$ & $18.56 \pm 1.03 \mathrm{ab}$ & $15.60 \pm 1.30 \mathrm{~b}$ \\
$5^{\text {th }}$ day & $49.07 \pm 1.05 \mathrm{a}$ & $39.98 \pm 3.18 \mathrm{a}$ & $35.65 \pm 2.03 \mathrm{ab}$ & $23.68 \pm 1.82 \mathrm{ab}$ & $18.69 \pm 1.59 \mathrm{~b}$ \\
$7^{\text {th }}$ day & $73.74 \pm 4.18 \mathrm{a}$ & $59.08 \pm 4.08 \mathrm{a}$ & $45.30 \pm 3.50 \mathrm{ab}$ & $28.81 \pm 3.02 \mathrm{~b}$ & $24.60 \pm 2.86 \mathrm{~b}$ \\
$10^{\text {th }}$ day & $80.43 \pm 4.72 \mathrm{a}$ & $67.58 \pm 6.14 \mathrm{a}$ & $58.00 \pm 5.57 \mathrm{ab}$ & $35.69 \pm 4.37 \mathrm{ab}$ & $29.38 \pm 3.59 \mathrm{~b}$ \\
\hline $14^{\text {th }}$ day & &
\end{tabular}

Note. Values are the average of ten replicates per treatment \pm SE. The letters indicate the comparison among the different essential oil concentrations evaluated in each day (per line). Means followed by same letter do not differ by Dunnett's T3 test $(\mathrm{p}<0.05)$.

\subsubsection{Antifungal Activity of Essential Oil on Conidia Germination}

Germination of conidia of $B$. cinerea was inhibited completely at concentration $100 \mathrm{ppm}$, while the complete inhibition for C. acutatum was at concentration $200 \mathrm{ppm}$ (Figure 1). The concentrations of 10 and $50 \mathrm{ppm}$ 
showed a significant reduction in the germination of conidia of $B$. cinerea and in the length of the germ tube (data not shown).

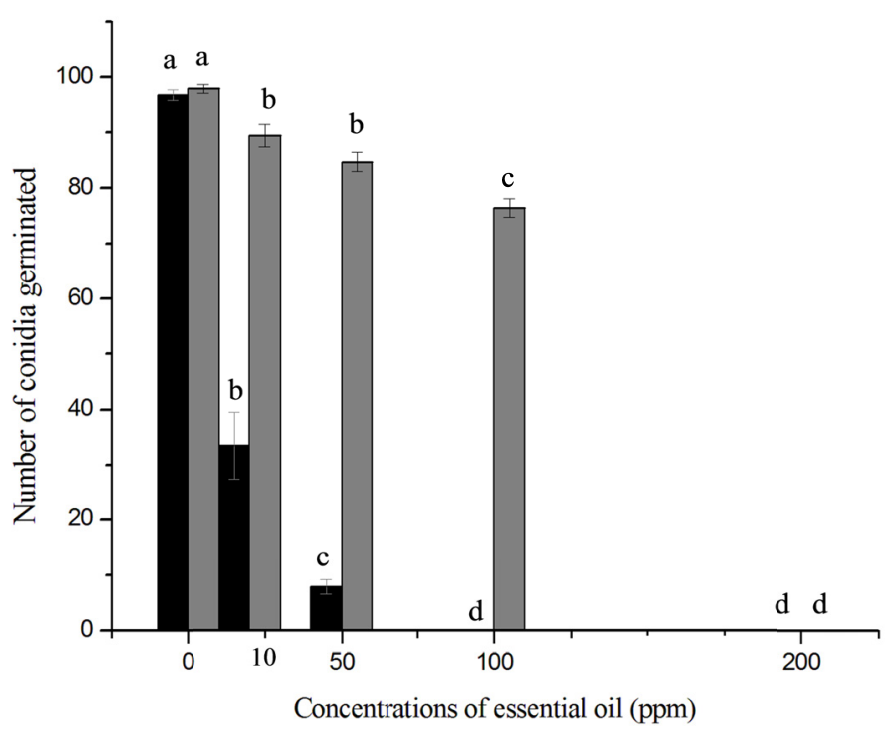

Figure 1. Effect of different concentrations of Foeniculum vulgare essential oil on conidia germination of Botrytis cinerea $(\mathbf{\bullet})$ and Colletotrichum acutatum $(\square)$

Note. Values are the average of ten replicates per treatment \pm SE. Means followed by same letter do not differ by Dunnett's T3 test $(\mathrm{p}<0.05)$.

\subsection{Antifungal Activity of Essential Oil in Postharvest Grapes}

Different concentrations of $F$. vulgare essential oil were efficient, reducing the incidence of disease caused by $B$. cinerea and $C$. acutatum, both in preventive and curative treatment. In the preventive treatment of $B$. cinerea, all essential oil concentrations (100 and $200 \mathrm{ppm}$ ) were able to reduce the incidence when compared to control. The curative treatment proved to be more efficient and at the concentration $200 \mathrm{ppm}$ no incidence of disease was detected (Figure 2A). In the preventive treatment of C. acutatum concentration $200 \mathrm{ppm}$ was able to inhibit the incidence of the disease, being different of control. Similarly to the test with $B$. cinerea the curative treatment of C. acutatum proved to be more efficient, concentrations 50 and $100 \mathrm{ppm}$ significantly reduced disease incidence, while the concentration $200 \mathrm{ppm}$ presented no incidence of disease (Figure 2B). The severity of both diseases, showed no significant difference in treatments with essential oil compared to control when the disease was detected (data not shown). The grape clusters treated with essential oil of F. vulgare did not show any obvious signs of phytotoxicity, just showed up brighter. 
(a)

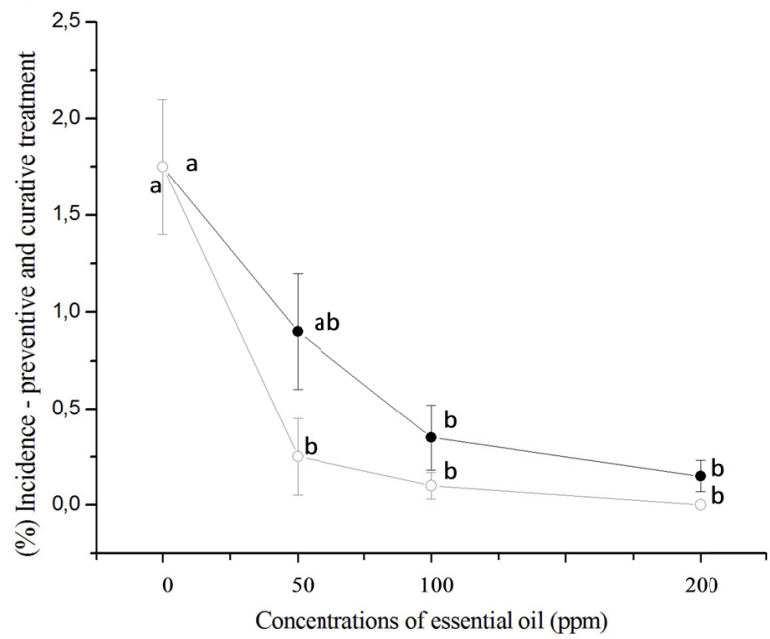

(b)

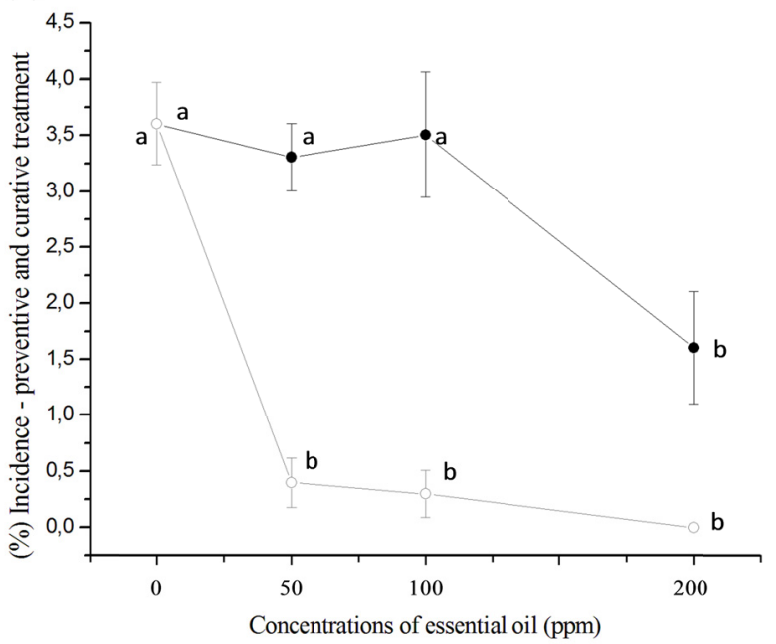

Figure 2. The effects of different concentrations of essential oil of Foeniculum vulgare against fungal rots in grapes. Incidence of disease caused by Botrytis cinerea (a) and Colletotrichum acutatum (b) as to preventive (•) and curative $(0)$ treatment

Note. Values are the average of ten replicates per treatment \pm SE. Means followed by same letter do not differ by Dunnett's T3 test $(\mathrm{p}<0.05)$.

\section{Discussion}

The increasing social and economic implications caused by fungi diseases means that there is a constant striving to produce safer food and to develop new antifungal agents (Feng \& Zheng, 2007). Essential oils are complex, volatiles and natural compounds of plants, known by its antiseptic, bactericides and fungicides characteristics (Bakkali, S. Averbeck, D. Averbeck, \& Idaomar, 2008). The antifungal property of several essential oils on postharvest pathogens of fruits and vegetables under in vitro and in vivo conditions has been investigated (Feng \& Zheng, 2007; Zambonelli, Zechini D’Aulerio, Bianchi, \& Albasini, 1996).

The essential oil of $F$. vulgare used in this experiment contained high levels of trans-anethole (79.14\%) as well as fenchone and estragole as major compounds, similarly to the results reported by Roby, Sarhan, Selim and Khalel (2013) that found trans-anethole (65.4\%), fenchone (8.26\%), estragole (5.2\%) and limonene (4.2\%) as the major components of $F$. vulgare essential oil. A literature search revealed that there are variations in the composition and proportion of the major compounds. Kazemi, Rostami and Shafiei (2012) informed that the major components of $F$. vulgare essential oil were trans-anethole and fenchone, while Diao, Hu, Zhang, and Xu(2014), Viuda-Martos et al. (2011), Mota et al. (2015) and Telci et al. (2009) found that trans-anethole, estragole, limonene and fenchone in different proportions were the major compounds in the essential oil of Chinese fennel, Egyptian fennel, Portuguese fennel and sweet fennel cultivated in Turkey, respectively. These differences in components and its content on essential oil from fennel may be concerned in the geographical origins (Diaz-Maroto et al., 2006), cultivated varieties and maturity of fennel fruits, as well as extraction methods (Mimica-Dukié, Kujundzié, Sokovié, \& Couladis, 2003; M. C. Diaz-Maroto, H. I. J. Díaz-Maroto, Sanchez-Polomo, \& Pérez-Coello, 2005).

The in vitro data presented in this study indicated that $F$. vulgare essential oil had a fungistatic effect at low concentrations and fungicidal effect at higher concentrations. The concentration of essential oil required to completely inhibiting mycelial growth and conidia germination of C. acutatum was greater than the concentration used for $B$. cinerea. The essential oil of $F$. vulgare has also been reported to reduce the mycelial growth of Sclerotinia sclerotiorum and as such could be used as biofungicide against this phytopathogenic fungus (Soylu et al., 2007). The essential oil of fennel has been reported to show complete inhibition against Aspergillum niger, Aspergillum flavus, Fusarium graminearum and Fusarium moniliforme (Singh et al., 2006). The effect of essential oils on microbial growth was reported by Fung, Taylor, and Kahan (1977) and Tian et al. (2012) who suggested that it might be the result of phenolic compounds and terpenoids present in the essential oils altering microbial cell permeability by interacting with membrane proteins. This would cause deformation of cell structure and functionality and permit the loss of macromolecules from their interior (Pramila et al., 2012). 
Being lipophilic in nature, essential oil accumulates in plasma membrane, causes swelling of the membrane and makes the membrane proteins inefficient due to increased disorder. This ultimately causes leakage of cell contents and inhibition of cell growth (Helal, Sarhan, Abu Shahla, \& Abou El-Khair, 2007). Moreover, each essential oil component makes its own contribution to the biological activity of the oil. The volatile phase of essential oil showed a fungistatic action, partially inhibiting the mycelial growth of fungi. Volatile phase of artemisia, peppermint, basil and thyme essential oils were also reported to posses antimicrobial activity against plant pathogenic fungi (Edris \& Farrag, 2003; Soylu et al., 2005). Investigators suggested that the antifungal activity resulted from a direct effect of essential oil vapours on fungal mycelium and postulated that the lipophilic nature of essential oils would make possible for them being absorbed by fungal mycelia (Edris \& Farrag, 2003; Inouye et al., 2000). In this work, both fungi hyphae grown on media with essential oils revealed alterations in the morphology. Such modifications may be related to the effect of the essential oil on enzymatic reactions regulating wall synthesis for example (Rasooli, Rezaei, \& Allameh, 2013).

Soylu et al. (2007) reported the reduction of germination of Sclerotinia sclerotiorum and Aminifard and Mohammadi (2013) reported that conidia germination and germ tube elongation of $B$. cinerea were inhibited by $F$. vulgare essential oil. Our results corroborated with that as the essential oil of $F$. vulgare also inhibited conidia germination of $B$. cinerea and $C$. acutatum. Besides inhibiting the mycelial growth, phenolic compounds also affect the enzymes responsible for conidia germination and interfere with amino acids that were necessary in germination processes (Nychas, 1995).

The in vivo test showed that the essential oil of fennel had a positive effect in controlling the incidence of postharvest fungal rots on grapes caused by $B$. cinerea and $C$. acutatum. Essential oil inhibits postharvest pathogens mainly due to their direct effect on the mycelial growth of the pathogens and conidia germination by affecting the cellular metabolism of the pathogens (Serrano, Martínez-Romero, Castillo, Guillen, \& Valero, 2005; Tzortzakis, 2007a, 2007b; Regnier, Combrinck, Du Ploov, \& Botha, 2010). Prior studies of fennel essential oil has shown better efficacy against postharvest fungi including Aspergillus species in different test methods (Singh et al., 2006; Barkat \& Bouguerra, 2012; Gemeda, Woldeamanuel, Asrat, \& Debella, 2014). According to Abdolari, Hassani, Ghosta, Javadi, and Meshkatalsadat (2010), fennel essential oil had good inhibitory effects on infection caused by Alternaria alternata and Penicillium digitatum in postharvest tomato fruits. According to Aminifard and Mohammadi (2013), fennel essential oil inhibited B. cinerea growth on plum fruits compared with the control. Lopez-Reyes, Spadaro, Gullinoa, and Garibaldua (2010) proved that the essential oil of fennel has antifungal activity as postharvest treatments against $B$. cinerea and Penicillium expansum on apples.

Results showed that antifungal activities of essential oils were different under in vitro and in vivo conditions and these activities were higher under in vitro conditions, requiring a higher concentration of the essential oil in vivo. Dikbas, Kotan, Dadasoglu, and Sahin (2008) noticed that these differences could be attributed to the alternation of site of action of essential oils or alternation in membranes of fungi under in vivo condition.

\section{Conclusions}

Considering the inhibition in mycelial growth and germination of conidia of B. cinerea and C. acutatum in vitro, and the reduced incidence of disease symptoms on essential oil treated grapes fruits, we can conclude that $F$. vulgare (fennel) essential oil could be used as possible biofungicide. However, more studies are required before this essential oil can be recommended as commercial and natural antifungal agent to increase the postharvest storage life of grapes.

\section{References}

Abdolahi, A., Hassani, A., Ghosta, Y., Javadi, T., \& Meshkatalsadat, M. H. (2010). Essential oils as control agents of postharvest Alternaria and Penicillium rots on tomato fruits. Journal of Food Safety, 30, 341-352. http://dx.doi.org/10.1111/j.1745-4565.2009.00211.x

Adams, R. P. (2005). Identification of essential oil components by gas chromatography/mass spectroscopy (p. 469). Allured Publishing Corporation, Carol Stream, IL, USA.

Agostini, F., Santos, A. C. A., Rossato, M., Pansera, M. R., Santos, P. L., Serafini, L. A., ... Moyna, P. (2009). Essential oil yield and composition of Lamiaceae species growing in Southern Brazil. Brazilian Arquives of Biology and Technology, 52(2), 473-478. http://dx.doi.org/10.1590/S1516-89132009000200026

Aminifard, M. H., \& Mohammadi, S. (2013). Essential oils to control Botrytis cinerea in vitro and in vivo on plum fruits. J Sci Food Agric, 93, 348-353. http://dx.doi.org/10.1002/jsfa.5765 
Badawy, M. E., \& Rabea, E. I. (2013). Synthesis and structure-activity relationship of N-(cinnamyl) chitosan analogs as antimicrobial agents. International $J$ of Biological Macromolecules, 57, $185-192$. http://dx.doi.org/10.1016/j.ijbiomac.2013.03.028

Bakkali, F., Averbeck, S., Averbeck, D., \& Idaomar, M. (2008). Biological effects of essential oils: A review. Food and Chemical Toxicology, 46(2), 446-475. http://dx.doi.org/10.1016/j.fct.2007.09.106

Barkat, M., \& Bouguerra, A. (2012). Study of the antifungal activity of essential oil extracted from seeds of Foeniculum vulgare Mill. for its use as food conservative. Afr J Food Sci, 6, 239-244. http://dx.doi.org/10.5897/AJFS12.021

Chao, S. C., \& Young, D. G. (2000). Screening for inhibitory activity of essential oils on selected bacteria, fungi and viruses. J Essentials Oil Research, 12, 630-649. http://dx.doi.org/10.1080/10412905.2000.9712177

Choi, E. M., \& Hwang, J. K. (2004). Anti-inflammatory, analgesic anda antioxidant activities of the fruit of Foeniculum vulgare. Fitoterapia, 75, 557-565. http://dx.doi.org/10.1016/j.fitote.2004.05.005

Diao, W., Hu, Q., Zhang, H., \& Xu, J. (2014). Chemical composition, antibacterial activity and mechanism of action of essential oil from seeds of fennel (Foeniculum vulgare Mill.). Food Control, 35, 109-116. http://dx.doi.org/10.1016/j.foodcont.2013.06.056

Diaz-Maroto, M. C., Díaz-Maroto, H. I. J., Sánchez-Palomo, E., \& Pérez-Coello, M. S. (2005). Volatile components and key odorants of fennel (Foeniculum vulgare Mill.) and thyme (Thymus vulgaris L.) oil extracts obtained by simultaneous distillation-extraction and supercritical fluid extraction. $J$ of Agricultural and Food Chemistry, 53, 5385-5389. http://dx.doi.org/10.1021/jf050340+

Diaz-Maroto, M. C., Pearez-Coello, M. S., Esteban, J., \& Sanz, J. (2006). Comparison of the volatile composition of wild fennel samples (Foeniculum vulgare Mill.) from Central Spain. J Agric Food Chem, 54, 6814-6818. http://dx.doi.org/10.1021/jf0609532

Dikbas, N., Kotan, R., Dadasoglu, F., \& Sahin, F. (2008). Control of Aspergillus flavus with methanol and extracts of Satureja hortensis. Int J Food Microbiol, 124, 179-182. http://dx.doi.org/10.1016/j.ijfoodmicro. 2008.03.034

Droby, S., \& Lichter, A. (2004). Postharvest Botrytis infection: Etiology, development and management. In Y. Elad, B. Williamson, P. Tudzynski, \& N. Delen (Eds.), Botrytis: Biology, Pathology and Control (pp. 349-367). Kluwer Academic Publishers, Dor-drecht, The Netherlands.

Edris, A. E., \& Farrag, E. S. (2003). Antifungal activity of peppermint and sweet basil essential oils and their major aroma constituents on some plant pathogenic fungi from the vapour phase. Nahrung/Food, 47, 117-121. http://dx.doi.org/10.1002/food.200390021

El-Soud, N. A., El-Laithy, N., El-Saeed, G., Wahby, M. S., Khalil, M., Morsy, F., \& Shaffie, N. (2011). Antidiabetic activities of Foeniculum vulgare Mill. essential oil in Streptozotocin induced diabetic rats. Macedonian J Med Sci, 173, 1857-5773. https://doi.org/10.3889/MJMS.1857-5773.2011.0173

Feng, W., \& Zheng, X. (2007). Essential oils to control Alternaria alternata in vitro and in vivo. Food Control, 18, 1126-1130. http://dx.doi.org/10.1016/j.foodcont.2006.05.017

Fung, D. Y. C., Taylor, S., \& Kahan, J. (1977). Effects of butylated hydroxyanisole (BHA) and butylated hydroxytoluene (BHT) on growth and aflatoxin production of Aspergillus flavus. J Food Saf, 1, 39-51. http://dx.doi.org/10.1111/j.1745-4565.1977.tb00258.x

Gemeda, N., Woldeamanuel, Y., Asrat, D., \& Debella, A. (2014). Effect of Cymbopogon martinii, Foeniculum vulgare and Trachyspermum ammi essential oils on the growth and mycotoxins production by Aspergillus species. Int J Food Sci, 1-9. http://dx.doi.org/10.1155/2014/874135

Gonzáles-Aguilar, G. A., Ruizcruz, S., Cruz-Valenzuela, R., Ayala-Zavala, J. F., Rosa, L. A., \& Alvarez-Parrilla, E. (2008). New technologies to preserve quality of fresh cut produce. In G. F. Gutiérrez-López, G. V. Barbosa-Cánovas, J. Welti-Chanes \& E. Parada-Arias (Eds.), Food Engineering Integrated Approaches. New York: Springer.

Helal, G. A., Sarhan, M. M., Abu Shahla, A. N. K., \& Abou El-Khair, E. K. (2007). Effects of Cymbopogon citratus L. essential oil on the growth: Morphogenesis and aflatoxin production of Aspergillus flavus ML2-strain. J Basic Microbiol, 47, 5-15. http://dx.doi.org/10.1002/jobm.200610137 
Inouye, S., Tsuruoka, T., Watanabe, M., Takeo, K., Akao, M., Nishiyama, Y., \& Yamaguchi, H. (2000). Inhibitory effect of essential oils on apical growth of Aspergillus fumigatus by vapour contact. Mycoses, 43, 17-23. http://dx.doi.org/10.1046/j.1439-0507.2000.00538.x

Kazemi, M., Rostami, H., \& Shafiei, S. (2012). Antibacterial and antifungal activity of some medicinal plants from Iran. J Plant Sci, 7, 55-66. http://dx.doi.org/10.3923/jps.2012.55.66

Lee, S. H. (2004). Acaricidal activity of constituents identified in Foeniculum vulgare fruit oil against Dermatophagoides spp. (Acari: Pyroglyphidae). J Agric Food Chem, 52, 2887-2889. http://dx.doi.org/ $10.1021 / \mathrm{jf0} 49631 \mathrm{t}$

Lichter, A., Zutkhy, Y., Sonego, L., Dvir, O., Kaplunov, T., Sarig, P., \& Benarie, R. (2002). Ethanol controls postharvest decay of table grapes. Postharvest Biology and Technology, 24, 301-308. http://dx.doi.org/ 10.1016/S0925-5214(01)00141-7

Lopez-Reyes, J. G., Spadaro, D., Gullinoa, M. L., \& Garibaldia, A. (2010). Efficacy of plant essential oils on postharvest control of rot caused by fungi on four cultivars of apples in vivo. Flavour and Fragrance Journal, 25, 171-177. http://dx.doi.org/10.1002/ffj.1989

Mello, L. M. R. (2014). Vitivinicultura brasileira: Panorama 2013. Embrapa Uva e Vinho (Comunicado Técnico 156).

Mimica-Dukié, N., Kujundzié, S., Sokovié, M., \& Couladis, M. (2003). Essential oil composition and antifungal activity of Foeniculum vulgare Mill. obtained by different distillation conditions. Phytotherapy Res, 17, 368-371. http://dx.doi.org/10.1002/ptr.1159

Mlikota Gabler, F., \& Smilanick, J. L. (2001). Postharvest control of table grape gray mold on detached berries with carbonate and bicarbonate salts and disinfectants. Am J Enol Vitic, 52, 12-20.

Mota, A. S., Martins, M. R., Arantes, S., Lopes, V. R., Bettencourt, E., Pombal, S., ... Silva, L. A. (2015). Antimicrobial activity and chemical composition of the essential oils of Portuguese Foeniculum vulgare fruits. Nat Prod Commum, 10(4), 673-676.

Murray, M. G., \& Thompson, W. F. (1980). Rapid isolation of high molecular weight plant DNA. Nucleic Acid Research, 8, 4321-4326.

Nychas, G. J. E. (1995). Natural antimicrobials from plants. In G. W. Gould (Ed.), New Methods of Food Preservation (pp. 58-89). Blackie Academic Professional, London.

Ozbek, H., Ugras, S., Dulger, H., Bayram, I., Tuncer, I., Ozturk, G., \& Ozturk, A. (2003). Hepatoprotective effect of Foeniculum vulgare essential oil. Fitoterapia, 74, 317-319. http://dx.doi.org/10.1016/S0367-326X (03)00028-5

Pearson, R. C., \& Goheen, A. C. (1988). Compendium of Grape Diseases (p. 96). APS Press, MN, USA.

Peres, N. A. R., Kuramae, E. E., Dias, M. S. C., \& Souza, N. L. (2002). Identification and characterization of Colletotrichum spp. affecting fruit after harvest in Brazil. $J$ Phytopathology, 150, 128-134. http://dx.doi.org/10.1046/j.1439-0434.2002.00732.x

Pradhan, M., Sribhuwaneswari, S., Karthikeyan D., Minz, S., Sure, P., Chandu, A. N., ... Sivakumar, T. (2008). In vitro cytoprotection activity of Foeniculum vulgare and Helicteres isora in cultured human blood lymphocytes and antitumour activity against B16F10 melanoma cell line. Res J Pharm Technol, 1(14), 450-452.

Pramila, D. M., Xavier, R, Marimuthu, K., Kathiresan, S., Khoo, M. L., \& Senthilkumar, M. (2012). Phytochemical analysis and antimicrobial potential of methanolic leaf extract peppermint (Menthapiperita). J Med Plants Res, 6, 331-335. http://dx.doi.org/10.5897/JMPR11.1232

Rasooli, I., Rezaei, M. B., \& Allameh, A. (2006). Growth inhibition and morphological alterations of Aspergillus niger by essential oils from Thymus eriocalyx and Thymus x-porlock. Food Control, 17, 359-364. http://dx.doi.org/10.1016/j.foodcont.2004.12.002

Rather, M. A., Dar, B. A., Sofi, S. N., Bhat, B. A., \& Qurishi, M. A. (2012). Foeniculum vulgare: A comprehensive review of its traditional use, phytochemistry, pharmacology and safety. Arabian Journal of Chemistry. http://dx.doi.org/10.1016/j.arabjc.2012.04.011 
Regnier, T., Combrinck, S., Du Plooy, W., \& Botha, B. (2010). Evaluation of Lippia scaberrima essential oil and some pure terpenoid constituents as postharvest mycobiocides for avocado fruit. Postharvest Biol Tec, 57, 176-182. http://dx.doi.org/10.1016/j.postharvbio.2010.03.010

Roby, M. H. H., Sarhan, M. A., Selim, K. A.-H., \& Khalel, K. I. (2013). Antioxidant and antimicrobial activities of essential oil and extracts of fennel (Foeniculum vulgare L.) and chamomile (Matricaria chamomilla L.). Ind Crops Prod, 44, 437-445. http://dx.doi.org/10.1016/j.indcrop.2012.10.012

Romanazzi, G., Nigro, F., Ippolito, A., Di Venere, D., \& Salermo, M. (2002). Effects of pre and postharvest chitosan treatments to control storage grey mold of table grapes. Food Microbiology and Safety, 67(5), 1862-1867. http://dx.doi.org/10.1111/j.1365-2621.2002.tb08737.x

Ruberto, G., Baratta, M. T., Deans, S. G., \& Dorman, H. J. D. (2000). Antioxidant and antimicrobial activity of Foeniculum vulgare and Crithmum maritimum essential oils. Planta Med, 66, 687-693. http://dx.doi.org/10.1055/s-2000-9773

Serrano, M., Martínez-Romero, D., Castillo, S., Guillen, F., \& Valero, D. (2005). The use of antifungal compounds improves the beneficial effect of map in sweet cherry storage. Innov Food Sci Emerg Technol, 6, 115-123. http://dx.doi.org/10.1016/j.ifset.2004.09.001

Silva, V. S. (2012). Potencial alelopático do óleo essencial de espécies de Heterothalamus nativas do Rio Grande do Sul (Tese de Doutorado em Ciências: Botânica). Universidade Federal do Rio Grande do Sul, Brasil.

Silveira, S. V., Hoffmann, A., \& Garrido, L. R. (2015). Implantação do vinhedo, cultivares e manejo da planta (Volume 3). Embrapa, Brasilia, DF.

Singh, G., Maurya, S., de Lampasona, M. P., \& Catalan, C. (2006). Chemical constituents, antifungal and antioxidative potential of Foeniculum vulgare volatile oil and its acetone extract. Food Control, 17, 745-752 http://dx.doi.org/10.1016/j.foodcont.2005.03.010

Smilanick, J. L., Brown, G. E., \& Eckert, J. W. (2006). The biology and control of postharvest diseases. In W. F. Wardowski, W. M. Miller, D. J. Hall \& W. Grierson (Eds.), Fresh Citrus Fruits (2nd ed., pp. 339-396). Florida Science Source Inc., Longboat Key, FL, USA.

Soylu, E. M., Yigitbas, H., Tok, F. M., Soylu, S., Kurt, S., Baysal, O., \& Kaya, A. D. (2005). Chemical composition and antifungal activity of the essential oil of Artemisia annua L. against foliar and soil-borne fungal pathogens. Z Pflanzenk Pflanzen, 112, 229-239.

Soylu, S., Yigitbas, H., Soylu, E. M., \& Kurt, S. (2007). Antifungal effects of essential oils from oregano and fennel on Sclerotinia sclerotiorum. J Appl Microbiol, 103, 1021-1030. http://dx.doi.org/10.1111/j.1365-2672. 2007.03310.x

Steel, C. C., Greer, L. A., \& Savocchia, S. (2007). Studies on Colletotrichum acutatum and Greeneria uvicola: Two fungi associated with bunch rot of grapes in sub-tropical Australia. Aust J Grape Wine Res, 13, 23-29. http://dx.doi.org/10.1111/j.1755-0238.2007.tb00068.x

Telci, I., Demirtas, I., \& Sachin, A. (2009). Variation in plant properties and essential oil composition of sweet fennel (Foeniculum vulgare Mill.) fruit during stages of maturity. Ind Crops Prod, 30, 126-130. http://dx.doi.org/10.1016/j.indcrop.2009.02.010

Thomas, C. S., Marois, J. J., \& English, J. T. (1988). The effects of wind speed, temperature, and relative humidity on development of aerial mycelium and conidia of Botrytis cinerea on grape. Phytopathology, $78(3), 260-265$.

Tian, J., Ban, X., Zeng, H., He, J., Chen, Y., \& Wang, Y. (2012). The mechanism of antifungal action of essential oil from dill (Anethum graveolens L.) on Aspergillus flavus. PloS One, 7(1), 30147. http://dx.doi.org/ 10.1371/journal.pone.0030147

Tognolini, M., Ballabeni, V., Bertoni, S., Bruni, R., Impicciatore, M., \& Barocelli, E. (2007). Protective effect of Foeniculum vulgare essential oil and anethole in an experimental model of thrombosis. Pharmacol Res, 56, 254-260. http://dx.doi.org/10.1016/j.phrs.2007.07.002

Tomazoni, E. Z., Pansera, M. R., Pauletti, G. F., Moura, S., Ribeiro, R. S. T., \& Schwambach, J. (2016). In vitro antifungal activity of four chemotypes of Lippia alba (Verbenaceae) essential oils against Alternaria solani (Pleosporeaceae) isolates. Anais da Academia Brasileira de Ciências, 88(2), 999-1010. http://dx.doi.org/ 10.1590/0001-3765201620150019 
Tzortzakis, N. G. (2007a). Maintaining postharvest quality of fresh produce with volatile compounds. Innov Food Sci Emerg Technol, 8, 111-116. http://dx.doi.org/10.1016/j.ifset.2006.08.001

Tzortzakis, N. G. (2007b). Methyl jasmonate-induced suppression of anthracnose rot in tomato fruit. Crop Prot, 26, 1507-1513. http://dx.doi.org/10.1016/j.cropro.2006.12.014

Viuda-Martos, M., Mohamady, M. A., Fernandez-Lopez, J., Abd Elrazik, K. A., Omer, E. A., Perez-Alvarez, J. Á., \& Sendra, E. (2011). In vitro antioxidant and antibacterial activities of essentials oils obtained from Egyptian aromatic plants. Food Control, 22, 1715-1722. http://dx.doi.org/10.1016/j.foodcont.2011.04.003

White, T. J., Bruns, T., Lee, S., \& Taylor, J. W. (1990). Amplification and direct sequencing of fungal ribosomal RNA genes for phylogenetics. In M. A. Innis (Ed.), PCR protocols: A guide to methods and applications (pp. 315-322). San Diego: Academic.

Whitelaw-Weckert, M. A., Curtin, S. J., Huang, R., Steel, C. C., Blanchard, C. L., \& Roffey, P. E. (2007). Phylogenetic relationships and pathogenicity of Colletotrichum acutatum isolates from grape in subtropical Australia. Plant Pathol, 56, 448-463. http://dx.doi.org/10.1111/j.1365-3059.2007.01569.x

Youssef, K., \& Roberto, S. R. (2014). Applications of salt solutions before and after harvest affect the quality and incidence of postharvest gray mold of 'Italia' table grapes. Postharvest Biology and Technology, 87, 95-102. http://dx.doi.org/10.1016/j.postharvbio.2013.08.011

Zahavi, T., Cohen, L., Weiss, B., Schena, L., Daus, A., Kaplunov, T., Zutkhi, J., Ben-Arie, R., \& Droby, S. (2000). Biological control of Botrytis, Aspergillus and Rhizopus rots on table and wine grapes in Israel. Postharvest Biology and Technology, 20(2), 115-124. http://dx.doi.org/10.1016/S0925-5214(00)00118-6

Zambonelli, A., Zechini D'Aulerio, A., Bianchi, A., \& Albasini, A. (1996). Effects of essential oil on phytopathogenic fungi. J Phytopathol, 144, 491-49. http://dx.doi.org/10.1111/j.1439-0434.1996.tb00330.x

\section{Copyrights}

Copyright for this article is retained by the author(s), with first publication rights granted to the journal.

This is an open-access article distributed under the terms and conditions of the Creative Commons Attribution license (http://creativecommons.org/licenses/by/4.0/). 